\title{
A TEST OF THE PRECISION OF THE HABITAT QUALITY INDEX MODEL II
}

\author{
Jeffrey S. Hogle Thomas A. Wesche \\ Wayne A. Hubert
}

1993

Journal Article

WWRC-93-16

In

North American Journal of Fisheries Management

\author{
Jeffrey S. Hogle and Thomas A. Wesche \\ Department of Range Management \\ and \\ Wyoming Water Resources Center \\ University of Wyoming \\ Laramie, Wyoming \\ Wayne A. Hubert \\ U.S. Fish and Wildlife Service \\ Wyoming Cooperative Fish and Wildlife \\ Resources Unit \\ University of Wyoming \\ Laramie, Wyoming
}




\title{
A Test of the Precision of the Habitat Quality Index Model II
}

\author{
JefFrey S. Hogle ANd Thomas A. Wesche \\ Department of Range Management and Wyoming Water Research Center \\ University of Wyoming, Laramie, Wyoming 82071-3354, USA \\ WAYNe A. HUBERT \\ U.S. Fish and Wildlife Service, Wyoming Cooperative Fish and Wildlife Resources Unit ${ }^{1}$ \\ University of Wyoming, Laramie, Wyoming 82071-3166, USA
}

\begin{abstract}
We assessed the precision of the habitat quality index (HQI) model II, a model for rating habitat quality in trout streams and predicting fish standing stocks. This is a deterministic model, and its precision depends on the ability of observers to generate similar input values. Three $50-\mathrm{m}$ stream reaches were evaluated by three teams per reach. Among individual attributes, measurements of cover and eroding bank had the greatest variability. Our results demonstrate the need for more thorough definition of these attributes to reduce subjectivity and associated measurement variability.
\end{abstract}

A review of mathematical models that predict standing stocks of stream fishes from habitat variables was compiled by Fausch et al. (1988). Such models are sometimes perceived as being of little practical value. A common criticism is that model predictions are not precise enough for management application. Because a deterministic mathematical model generates the same output if input values remain the same, the model's precision (repeatability) is affected by the ability of an observer, or of different observers measuring the same condition, to repeatedly produce the same answer (Platts et al. 1983). Lack of precision in field measurements is often related to observer bias or error and inadequate standardization. A model deemed to have good precision could be a useful tool for fisheries managers.

In the western United States, the habitat quality index (HQI) developed by Binns and Eiserman (1979) is widely used for rating habitat quality in trout streams and predicting standing stocks. Model II of the HQI requires assessment of nine habitat features (Binns 1979) that are rated, based on standardized criteria, from 0 (worst) to 4 (best). Ratings are inserted into the model's formula to pre-

\footnotetext{
1 The Unit is jointly supported by the University of Wyoming, the Wyoming Game and Fish Department, and the U.S. Fish and Wildlife Service.
}

dict potential standing stock of trout (range, 0 $1,083 \mathrm{~kg} / \mathrm{hectare})$.

Accuracy of the HQI (the degree to which a predicted trout standing stock corresponds to the true trout standing stock) has been tested with relatively good results in the Rocky Mountains (Conder and Annear 1987; Scarnecchia and Bergersen 1987; Kozel and Hubert 1989) but poor performance elsewhere (Bowlby and Roff 1986). We conducted an experiment to assess HQI model II precision, defined as the degree to which independent teams of observers could generate the same model output.

\section{Methods}

Testing of the model was performed by 21 members of a graduate seminar in stream ecology at the University of Wyoming. The students received no formal training regarding $\mathrm{HQI}$ procedures prior to the experiment. Nine teams, each consisting of two or three students, conducted independent $\mathrm{HQI}$ evaluations. Each team was provided a copy of the HQI procedures manual (Binns 1982) and written directions emphasizing the importance of developing HQI scores without outside consultation or discussion with other teams, although discussion among team members was encouraged.

The study site was Spring Creek, a small channelized stream in an urban area of Laramie, $\mathrm{Wy}$ oming. Field work was conducted during October 25-30, 1991, when Spring Creek's discharge was $0.07 \mathrm{~m}^{3} / \mathrm{s}$. Three $50-\mathrm{m}$ HQI stations (upper, middie, and lower), located about $100 \mathrm{~m}$ apart, were selected for evaluation. These stations, chosen in a $0.5-\mathrm{km}$ stream reach, were judged by visual inspection to have relatively high habitat diversity. Salmonid species known to exist in the study area were rainbow trout Oncorhynchus mykiss, cutthroat trout $O$. clarki, brown trout Salmo trutta, and brook trout Salvelinus fontinalis.

Each team evaluated seven of the nine HQI model II variables in the field. Ratings for two 
TABLE 1.-Ratings and measured values for seven attributes of the habitat quality index (HQI) model II, as well as predicted potential trout standing crop. Values were determined by nine teams (1-9) at three stations (upper, middle, and lower) in Spring Creek, Wyoming, October 25-30, 1991.

\begin{tabular}{|c|c|c|c|c|c|c|c|c|c|}
\hline \multirow[b]{3}{*}{ Attribute } & \multicolumn{9}{|c|}{ Station } \\
\hline & \multicolumn{3}{|c|}{ Upper } & \multicolumn{3}{|c|}{ Middle } & \multicolumn{3}{|c|}{ Lower } \\
\hline & 1 & 2 & 3 & 4 & 5 & 6 & 7 & 8 & 9 \\
\hline \multicolumn{10}{|c|}{ Late summer streamflow } \\
\hline Rating & 2 & 4 & 3 & 4 & 4 & 4 & 4 & 4 & 4 \\
\hline \multicolumn{10}{|c|}{ Annual streamflow variation } \\
\hline Rating & 2 & 3 & 2 & $\cdot 3$ & 3 & 4 & 3 & 3 & 2 \\
\hline \multicolumn{10}{|l|}{ Cover } \\
\hline Rating & 1 & 2 & 1 & 2 & 0 & 0 & 1 & 2 & 1 \\
\hline Measured value & $15 \%$ & $27 \%$ & $19 \%$ & $34 \%$ & $7 \%$ & $8 \%$ & $23 \%$ & $39 \%$ & $25 \%$ \\
\hline \multicolumn{10}{|l|}{ Eroding banks } \\
\hline Rating & 3 & 2 & 1 & 3 & 3 & 3 & 0 & 0 & I \\
\hline Measured value & $16 \%$ & $35 \%$ & $57 \%$ & $17 \%$ & $6 \%$ & $16 \%$ & $92 \%$ & $98 \%$ & $74 \%$ \\
\hline \multicolumn{10}{|l|}{ Substrate } \\
\hline Rating & 1 & 0 & 1 & 1 & 1 & 1 & 1 & 1 & 1 \\
\hline \multicolumn{10}{|c|}{ Water velocity $(\mathrm{cm} / \mathrm{s})$} \\
\hline Rating & 2 & 2 & 2 & 2 & 2 & 2 & 2 & 3 & 3 \\
\hline Measured value & 20.4 & 17.4 & 17.1 & 18.9 & 18.9 & 21.0 & 24.1 & 33.5 & 33.5 \\
\hline \multicolumn{10}{|l|}{ Wetted width (m) } \\
\hline Rating & 2 & 2 & 2 & 2 & 2 & 2 & 2 & 1 & 2 \\
\hline Measured value & 2.1 & 2.1 & 2.2 & 2.1 & 2.2 & 2.1 & 2.1 & 1.8 & 2.1 \\
\hline \multicolumn{10}{|l|}{$\begin{array}{l}\text { Predicted potential } \\
\text { standing stock }\end{array}$} \\
\hline (kg/hectare) & 12 & 9 & 13 & 28 & 17 & 21 & 17 & 21 & 20 \\
\hline
\end{tabular}

variables, maximum summer stream temperature and nitrate nitrogen, were provided to all teams. No discharge records were available to aid in calculation of ratings for the late summer streamflow and annual streamflow variation attributes. Therefore, students followed the HQI procedures manual to rate these two attributes based upon careful observation of existing channel conditions. Each HQI station was evaluated by three teams. Resulting data were used to evaluate the measurement error associated with individual model variables and the effect of measurement error on model predictions.

For each HQI station, the number of independent observations $(N)$ required to generate an estimate of the mean HQI score within $20 \%$ of the true mean at the $10 \%$ significance level $(P=0.10)$ was calculated with the following formula (Burns 1966):

$$
N=\left(t^{2}\right)\left(S^{2}\right) /(a \cdot x)^{2}
$$

$t=$ tabular value with 2 df and $P=0.10$;

$S^{2}=$ variance of the measured value;

$a=$ accuracy desired in describing the mean (0.2);

$x=$ mean in a group of $n$ samples.

This formula was also used to determine the number of independent observations required to gen- erate an estimate of the mean measured values (within $20 \%$ of the true mean at a $P$ of 0.10 ) for the attributes cover, eroding bank, water velocity, and stream width. Rating of the other three variables (late-summer streamflow, annual streamflow variation, and substrate) involved qualitative judgements or no quantitative field measurements; therefore, the Burns (1966) equation was not applicable.

Our assessment of model precision, as well as measurement error of individual model variables, was based on the calculated values of $N$. We subjectively decided that if more than three observations made by different teams were needed to achieve the specified precision, then variability in rating the attribute was substantial.

\section{Results}

The measured values and ratings of the HQI attributes for all nine teams in their respective stations (upper, middle, and lower), as well as the model predictions (standing stock in kilograms per hectare), are presented in Table 1. Among measured values of the individual attributes, cover and eroding banks had the greatest variability. The greatest variability in cover measurements was in the middle station (range, $7-34 \%$ ), and in eroding bank measurements was in the upper station (range, $16-57 \%$ ). Among rated values of the individual 
TABle 2.-Number of independent observations $(N)$ required to generate an estimate of the cover, eroding bank, water velocity, and wetted-width attributes and to provide an HQI score within $20 \%$ of the true mean values $(P=0.10)$ for three stations (upper, middle, and lower) on Spring Creek, Wyoming, October 25-30, 1991.

\begin{tabular}{lccc}
\hline \multirow{2}{*}{$\begin{array}{l}\text { Attribute and } \\
\text { index }\end{array}$} & \multicolumn{3}{c}{ Station } \\
\cline { 2 - 4 } & Upper & Middle & Lower \\
\hline Cover & 19 & 187 & 19 \\
Eroding banks & 69 & 46 & 4 \\
Water velocity & 2 & 1 & 7 \\
Wetted width & 2 & 2 & 2 \\
HQI & 7 & 14 & 2 \\
\hline
\end{tabular}

attributes, the cover, eroding bank, and late-summer streamflow attributes showed greatest variability. The upper station showed greatest variability in ratings for both late-summer streamflow and eroding bank attributes. Greatest variability in the ratings for cover occurred in the middle station.

The annual streamflow variation, substrate, water velocity, and wetted-width attribute ratings did not vary by more than one in any of the three HQI iterations per station.

The number of observations needed to estimate standing stock from the model, with the specified precision, were 7,14 , and 2 for the upper, middle, and lower stations, respectively (Table 2). Variation in the measured values of individual model attributes resulted in a wide range of $N$ values. Highest predicted $N$ values for the measured attributes (Table 2) were 187 for cover (middle station), 69 for eroding bank (upper station), 7 for water velocity (lower station), and 2 for wetted stream width (all stations).

\section{Discussion}

The variability of ratings and measured values was greatest for attributes involving two streambank characteristics, cover and eroding banks. As cover measurement is subjective, the observed variability was not surprising. However, the variability in eroding streambank length was unexpected. Whereas other model II attributes are defined quantitatively (except late-summer streamflow and annual streamflow variation when discharge records are not available), the cover and eroding bank attributes are not. The range of measured values for these two attributes demonstrate a need for more thorough and perhaps quantitative definitions to reduce subjectivity and associated variability. For example, Wesche (1980) defined overhead cover for brown trout in small streams as specific areas having water depth of at least 15 $\mathrm{cm}$, water velocity of less than $15 \mathrm{~cm} / \mathrm{s}$, and overhead cover with a width of at least $9 \mathrm{~cm}$.

Based on our criteria that adequate precision is indicated by predicted values of $N$ of 3 or less, our hypothesis, that the variation in individual attribute evaluations and subsequent ratings would lead to substantial variation in model predictions, was accepted for the upper and middle HQI stations. At these stations, variability in measurements required several independent observations per station ( 7 in the upper and 14 in the middle) to estimate standing stocks of trout. However, data from the lower station suggest rejecting the hypothesis. Although variation in individual attribute evaluations and subsequent ratings existed in the lower station, they did not lead to large variation in model output $(N=2)$. Reduced variability for model output in the lower reach may be due to random variability of team scores, or to habitat homogeneity within the reach.

The major focus of many stream habitat improvement projects is to increase fish cover and decrease bank erosion. Given the variability among values derived by the teams in this study, changes in the amount of cover and eroding banks following treatment may not be detected by untrained personnel using the HQI model II. Although we did not compare the precision of values derived by trained verses untrained personnel, variation may be reduced with prior HQI model II training and experience.

\section{Acknowledgments}

We thank R. Baldwin, B. Budd, D. Cannon, C. Chamberlain, J. DeStaso, C. Goertler, L. Herger, L. Jensen, C. Keleher, D. Lanning, B. LaVoie, S. Loose, C. Mason, M. McKinstry, T. Patton, G. Pauley, K. Peacock, J. Petty, D. Spildie, C. Wenzel, and R. Wilkison for assistance in the field, and A. Binns, C. Hawkins, L. Miranda, and D. Oberlie for reviewing the manuscript. The project was supported by the Department of Range Management and the Department of Zoology and Physiology at the University of Wyoming.

\section{References}

Binns, N. A. 1979. A habitat quality index for Wyoming trout streams. Wyoming Game and Fish Department, Fishery Research Report 2, Cheyenne.

Binns, N. A. 1982. Habitat quality index procedures manual. Wyoming Game and Fish Department, Cheyenne.

Binns, N. A., and F. M. Eiserman. 1979. Quantification 
of fluvial trout habitat in Wyoming. Transactions of the American Fisheries Society 108:215-228.

Bowlby, J. N., and J. C. Roff. 1986. Trout biomass and habitat relationships in southern Ontario streams. Transactions of the American Fisheries Society 115:503-514.

Burns, J. W. 1966. How big a sample? Pages 161-162 in A. Calhoun, editor. Inland fisheries management. California Department of Fish and Game, Sacramento.

Conder, A. L., and T. C. Annear. 1987. Test of weighted usable area estimates from a PHABSIM model for instream flow studies on trout streams. North American Journal of Fisheries Management 7:339 350.

Fausch, K. D., C. L. Hawkes, and M. G. Parsons. 1988. Models that predict standing crop of stream fish from habitat variables: 1950-85. U.S. Forest Service General Technical Report PNW-213.
Kozel, S. J., and W. A. Hubert. 1989. Testing of habitat assessment models for small trout streams in the Medicine Bow National Forest, Wyoming. North American Journal of Fisheries Management 9:458464.

Platts, W. S., W. F. Megahan, and G. W. Minshall. 1983. Methods for evaluating stream, riparian, and biotic conditions. U.S. Forest Service General Technical Report INT-138.

Scarnecchia, D. L., and E. P. Bergersen. 1987. Trout production and standing crop in Colorado's small streams, as related to environmental features. North American Journal of Fisheries Management 7:315330.

Wesche, T. A. 1980. The WRRI trout cover rating method-development and application. University of Wyoming, Water Resources Research Institute Series Publication 78, Laramie. 